Intecoms: Journal of Information Technology and Computer Science

Volume 2 Nomor 1, Juni 2019

e-ISSN : 2614-1574

p-ISSN : 2621-3249

DOI : $\underline{\text { https://doi.org/10.31539/intecoms.v2i1.659 }}$

\title{
SISTEM PAKAR IQ DALAM PENGELOMPOKAN ANAK RETERDASI MENTAL DENGAN ALGORITMA K-MEANS
}

\section{EXPERT SYSTEM IQ IN COLLECTION OF MENTAL RETERDATION CHILDREN WITH K-MEANS ALGORITHM}

\author{
Novi Rahayu \\ Sekolah Tinggi Ilmu Administrasi (STIA) Bengkulu \\ Novierahayu1980@gmail.com
}

\begin{abstract}
Reterdated mental children are children who have an intellectual level below the average. mentally retarded children are children who have intellectual deficiencies or limitations, are below the normal average, so have difficulties in academic, communication, and social tasks, and require special education services. Expert system is one part of artificial intelligence which has recently experienced very rapid development. This study aims to help the Dharma Wanita Extraordinary School to place students and students into a class with groups that are equally backward by applying the K-Means algorithm. The design of this expert system uses Data Flow Diagrams (DFD) and the programming language used to build expert systems in this study is Visual Basic. The results of the expert system built in this study help in diagnosing the level of mental reterdation based on the symptoms given by the user and the level of mental reterdation based on possible values using the K-Means algorithm calculation.
\end{abstract}

Keywords:Expert System, Mental Retarded Children, K-Means Algorithm.

\begin{abstract}
ABSTRAK
Anak reterdasi mental adalah anak yang mempunyai tingkat intelektual di bawah rata-rata.anak reterdasi mental adalah anak yang mempunyai kekurangan atau keterbatasan dari segi mental intelektualnya, dibawah rata-rata normal, sehingga mengalami kesulitan dalam tugas-tugas akademik, komunikasi, maupun sosial, dan memerlukan layanan pendidikan khusus. Sistem pakar merupakan salah satu bagian kecerdasan buatan yang akhir-akhir ini mengalami perkembangan yang sangat pesat. Penelitian ini bertujuan membantu Sekolah Luar Biasa Dharma Wanita untuk menempatkan siswa dan siswi kedalam suatu kelas dengan kelompok keterbelakangan yang sama rata dengan menerapkan algoritma K-Means tersebut. Perancangan sistem pakar ini menggunakan Data Flow Diagram (DFD) dan Bahasa pemograman yang digunakan untuk membangun sistem pakar dalam penelitian ini adalah Visual Basic. Hasil sistem pakar yang dibangun dalam penelitian ini membantu dalam mendiagnosa tingkat reterdasi anak mental berdasarkan gejala-gejala yang diberikan oleh user dan tingkat reterdasi mental berdasarkan nilai-nilai kemungkinan menggunakan perhitungan algoritma K-Means.
\end{abstract}

Kata Kunci :Sistem Pakar, Anak Reterdasi Mental, Algoritma K-Means.

\section{PENDAHULUAN}

Pendidikan adalah hak seluruh warga negara tanpa membedakan asalusul, kasta maupun keadaan fisik seseorang, termasuk anak-anak yang mempunyai kelainan yang membutuhkan pembelajaran secara khusus sebagaimana di amanatkan dalam Undang-undang Nomor 20 Tahun 2003 tentang Sistem Pendidikan Nasional, hak anak untuk memperoleh pendidikan dijamin penuh tanpa adanya diskriminasi termasuk anak-anak yang mempunyai kelainan atau anak yang berkebutuhan khusus.

Dalam permasalahan pendidikan, tidak ada perbedaan antara anak yang normal perkembangan jasmani dan rohaninya, dengan anak yang mengalami kecacatan fisik, seperti anak yang mengalami kelemahan mental atau sering disebut reterdasi mental . Anak 
Reterdasi Mental memiliki fungsi intelektual tidak statis terhadap kelompok tertentu, termasuk beberapa ciri dari down syndrom, memiliki kelainan fisik dibanding temannya, tetapi mayoritas dari anak Reterdasi Mental terutama yang tergolong ringan terlihat sama seperti yang lainnya. Dari kebanyakan kasus banyak anak Reterdasi Mental terdeteksi setelah masuk sekolah tes IQ mungkin bisa dijadikan indikasi dari kemampuan mental seseorang.Kemampuan adaptif seseorang tidak selamanya tercermin pada hasil IQ latihan, perjalanan, motivasi, dan lingkungan sosial sangat besar pengaruh pada kemampuan adaptif seseorang.Anak berkebutuhan khusus dianggap berbeda dengan anak normal.Mereka dianggap sosok yang tidak berdaya, sehingga perlu dibantu dan dikasihani oleh karena itu, dalam memandang anak berkebutuhan khusus, haruslah melihat dari segi kemampuan sekaligus ketidakmampuannya. Untuk mengatasi permasalahan tersebut telah disediakan berbagai bentuk layanan pendidikan (sekolah) bagi mereka yaitu Pendidikan Luar Biasa (SLB) yang merupakan pendidikan bagi peserta didik yang memiliki tingkat kesulitan dalam mengikuti proses pembelajaran karena kelainan fisik, emosional, mental sosial atau memiliki potensi kecerdasan dan bakat istimewa.

SLB Dharma Wanita yang berada di kota Bengkulu adalah bagian dari sekolah yang turut membantu dalam perkembangan anak-anak yang berkebutuhan khusus, sekolah ini memberikan kebutuhan yang diperlukan bagi mereka-mereka yang di anggap tidak normal dalam kaca mata sosial bermasyarakat .Tunagrahita terbagi menjadi 3 kelas yaitu retardasi mental ringan, retardasi mental sedang, dan retardasi mental berat.Untuk mengetahui klasifikasi seorang anak tunagrahita tentunya bukan hal yang mudah karena harus mempelajari tingkah laku pada anak.

Tujuan yang hendak dicapai dan diperoleh adalah agar dapat membantu Sekolah Luar Biasa Dharma Wanita untuk menempatkan siswa dan siswi kedalam suatu kelas dengan kelompok keterbelakangan yang sama rata dengan menerapkan algoritma k-means tersebut.

Kecerdasan buatan berasal dari kata Artificial Intelligence yang mengandung arti tiruan atau kecerdasan.Secara harfiah Artificial Intelligence adalah kecerdasan buatan. Kecerdasan buatan adalah salah satu bidang dalam ilmu komputer yang membuat komputer agar dapat bertindak dan sebaik seperti manusia (menirukan kerja otak manusia). (Octavina \&Fadlil, 2014).

Pada aplikasi kecerdasan buatan ada 2 bagian utama yang sangat dibutuhkan yaitu (Wijaya, 2013); 1) basis pengetahuan (Knowledge Base), berisi fakta-fakta, teori pemikiran dan hubungan antara satu dengan yang lainnya, 2) motor Inferensi (Inference Engine) yaitu kemampuan menarik kesimpulan berdasarkan pengalaman.

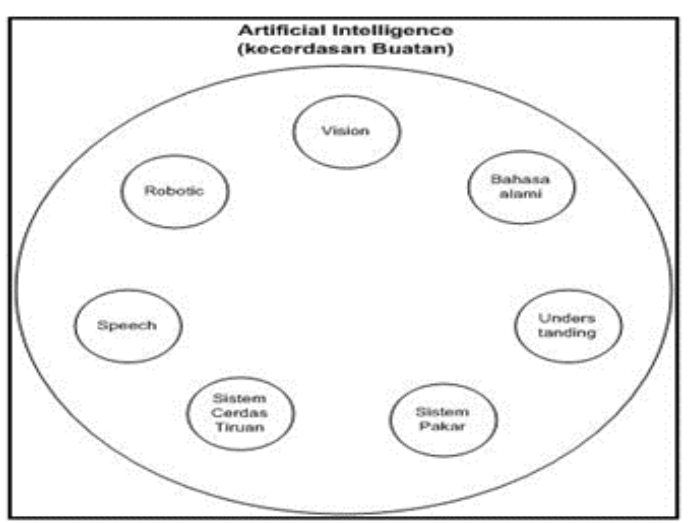

Gambar 1. Kecerdasan Buatan

Sistem pakar adalah suatu program komputer cerdas yang menggunakan pengetahuan (knowledge) dan prosedur inferensi untuk 
menyelesaikan masalah yang cukup sulit sehingga membutuhkan seorang yang ahli untuk menyelesaikannya (Widiastuti dkk, 2012).

Komponen-komponen sistem pakar sebagai berikut :

Antar muka merupakan mekanisme yang digunakan oleh pengguna sistem pakar untuk berkomunikasi.

Basis pengetahuan mengandung pengetahuan untuk pemahaman, formulasi dan penyelesaian masalah. Ada dua bentuk pendekatan basis pengetahuan yaitu; a) penalaran berbasis aturan (rule-based reasoning), b) pada penalaran berbasis aturan, pengetahuan direpresentasikan dengan menggunakan aturan berbentuk IF THEN, c) penalaran berbasis kasus (case-based reasoning) pada penalaran berbasis kasus, basis pengetahuan akan berisi solusi - solusi yang telah dicapai sebelumnya.

Akuisisi Pengetahuan adalah akumulasi, transfer dan transformasi keahlian dalam menyelesaikan masalah dari sumber pengetahuan ke dalam program komputer.

Mesin inferensi adalah program komputer yang memberikan metodologi untuk penalaran tentang informasi yang ada didalam basis pengetahuan dan dalam workplace dan untuk menformulasikan kesimpulan Ada dua jenis mesin inferensi yaitu; a) forward chaining, pencocokan fakta atau pernyataan dimulai dari bagian sebelah kiri dulu (IF dulu)(Supartini \& Hindarto, 2016), b) backward chaining, pencocokan fakta atau pernyataan dimulai dari bagian sebelah kanan (THEN dulu) (Mukhtar \& Samsudin, 2014).

Workplace merupakan area dari sekumpulan memory kerja. Fasilitas penjelasanmerupakan komponen tambahan yang akan meningkatkan kemampuan sistem pakar. Perbaikan pengetahuan, pakar memiliki kemampuan untuk menganalisis dan meningkatkan kinerja serta kemampuan belajar dari sistem pakar.

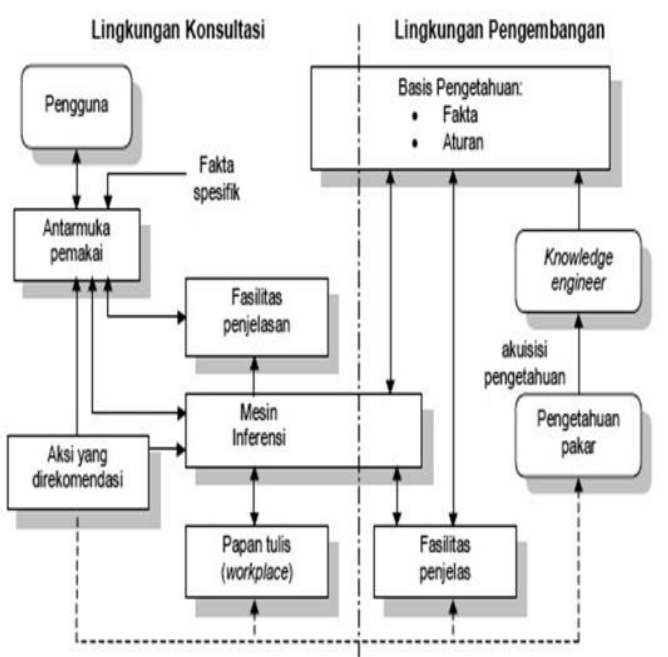

Gambar 2. Struktur Sistem Pakar

Retardasi mental adalah kelainan atau kelemahan jiwa dengan inteligensi yang kurang (subnormal) sejak masa perkembangan (sejak lahir atau sejak masa anak). Biasanya terdapat perkembangan mental yang kurang secara keseluruhan, tetapi gejala yang utama ialah inteligensi yang terbelakang (Sularyo \& Kadim, 2000).

Retardasi mental disebut juga oligofrenia (oligo: kurang atau sedikit dan fren: jiwa) atau tuna mental. Dari sekian banyak pengertian reterdasi mental, dapat disimpulkan bahwa reterdasi mental adalah suatu keadaan perkembangna jiwa yang terhenti atau tidak lengkap, yang terutama ditandai oleh terjadinya keterampilan selama masa perkembangan, sehingga berpengaruh pada tingkat kecerdasan secara menyeluruh, misalnya kemampuan kognitif, bahasa, motorik, sosial serta karakter yang dimiliki seperti anak yang normal (Daeli, 2013).

Terdapat banyak factor yang dapat menyebabkan seseorang menjadi tunagrahita. Para ahli dari berbagai ilmu 
telah berusaha membagi factor-factor penyebab ini diantaranya adalah sebagai berikut :

Faktor keturunan, adanya kelainan kromosom baik autosomse hingga anak mengalami Langdon Down's Syndrome dan pada trisomi anak akan menderita Patau's Syndrome. Adanya kegagalan meiosis sehingga menimbulkan duplikasi dan translokasi.

Gangguan metabolisme dan Gizi. Metabolisme dan gizi merupakan hal yang penting bagi perkembangan individu terutama perkembangan sel-sel otak. Beberapa kelainan yang disebabkan oleh kegagalan metabolisme dan kekurangan gizi diantaranya adalah sebagai berikut: a) phenylketonuria, kekurangan pigmen, microcephaly, serta kelainan tingkah laku, b) cretinisme, disebabkan oleh keadaan hypohyroidism kronik yang terjadi selama masa janin atau setelah melahirkan, c) infeksi dan keracunan. Adanya infeksi dan keracunan terjangkitnya penyakit - penyakit selama janin masih berada dalam kandungan ibunya yang menyebabkan anak lahir menjadi tunagrahita.

Masalah pada kelahiran. Adanya kelahiran yang disertai hypoxia (kejang dan nafas pendek) dipastikan bahwa bayi yang akan dilahirkan menderita kerusakan otak.

Faktor lingkungan. Kurangnya kesadaran orang tua akan pentingnya pendidikan dini serta kurangnya pengetahuan dalam memberikan segala rangsang-rangsang positif dalam masa perkembangan anak dapat menjadi salah satu penyebab timbulnya gangguan atau hambatan dalam perkembangan anak. Kondisi demikian akan berpengaruh buruk terhadap perkembangan anak baik fisik maupun mental intelektualnya.
Peran keluarga. Peran Keluarga tidak terlepas dari pola asuh yang diterapkan Orang tua dalam keluarga, dan dukungan orang tua dalam setiap perkembangan anak. Dalam orientasi tradisional, peranan ibu itu adalah ekspresif, sedangkan orientasi perkembangan bersifat lebih luas, yaitu melihat peranan ayah sebagai proses psikologis yang memberikan pemenuhan kebutuhan emosional.

Tabel 1. Tabel Klasifikasi IQ

\begin{tabular}{ccl}
\hline NO & IQ & \multicolumn{1}{c}{ TARAF } \\
INTELIGENSI
\end{tabular}

K-Means merupakan algoritma clustering yang berulang-ulang. Algoritma K-Means dimulai dengan pemilihan secara acak $\mathrm{K}, \mathrm{K}$ disini merupakan banyaknya cluster yang ingin dibentuk (Bastian, 2018). Kemudian tetapkan nilai-nilai $\mathrm{K}$ secara random, untuk sementara nilai tersebut menjadi pusat dari cluster atau biasa disebut dengan centroid, mean atau "means". Hitung jarak setiap data yang ada terhadap masing-masing centroid menggunakan rumus Euclidian hingga ditemukan jarak yang paling dekat / minimum dari setiap data dengan centroid. Klasifikasikan setiap data berdasarkan kedekatannya dengan 
centroid. Lakukan langkah tersebut hingga nilai centroid tidak berubah. (Rismawan \&Kusumadewi , 2008).

Adapun perhitungan K-Means adalah sebagai berikut; 1) menentukan $\mathrm{k}$ sebagai jumlah cluster yang ingin di bentuk, 2) membangkitkan nilai random untuk pusat cluster awal (centroid), 3) menghitung jarak setiap data input terhadap masing - masing centroid menggunakan rumus jarak Eucliden (Eucliden Distance) hingga ditemukan jarak yang paling dekat dari setiap data dengan centroid.

Dimana : $\quad x i$ adalah data kriteria $\mu \mathrm{j}$ adalah centroid pada kluster ke-j

$$
\mathrm{d}\left(\mathrm{x}_{i}-\mu_{i}\right)=\sqrt{\left(x_{i}-\mu_{i}\right)^{2}} \text {. }
$$

Mengklasifikasikan setiap data berdasarkan kedekatannya dengan centroid (jarak terkecil).

Memperbaharui nilai centroid. Nilai centroid baru diperoleh dari ratarata kluster yang bersangkutan dengan menggunakan rumus :

$$
\mu j(t+1)=\frac{1}{N s j} \sum_{j \in S j} x_{j}
$$

Dimana : $\mu \mathrm{j}(\mathrm{t}+1)$ adalah centroid baru pada iterasi ke $(\mathrm{t}+1)$

Nsj adalah banyak data pada kluster $\mathrm{sj}$

Melakukan perulangan dari langkah b hingga e, sampai anggota tiap kluster tidak ada yang berubah . Jika langkah $f$ telah terpenuhi maka nilai pusat kluster pada iterasi terakhir akan digunakan sebagai parameter untuk menentukan klasifikasi data

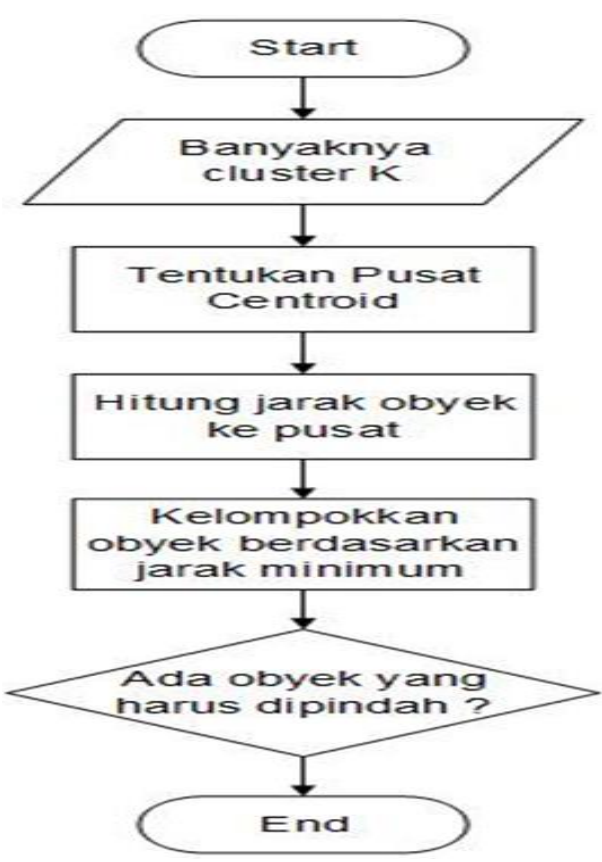

Gambar. 3 Diagram Alir K-Means

Bahasa pemrograman Visual Basic adalah sebuah perangkat lunak pemrograman komputer yang berorientasi pada grafik dan objek. Berorientasi objek atau object oriented merupakan pemrograman yang digunakan untuk menggambarkan banyak hal, seperti aplikasi yang user friendly, interface berbasis windows, lingkup pengembangan aplikasi, sistem operasi, teknologi database dan strategi komponen perangkat lunak. Berorientasi objek pada prinsipnya adalah menyimak masalah yang berdasarkan objek yang tercakup dalam masalah tersebut.Konsep berorientasi objek juga sudah diterapkan dalam banyak sisi dan profesi, misalnya sewaktu merancang sebuah unit perkantoran. Seorang arsitek akan merancang ruang kerja, pondasi dan frame work atau rencana kerja yang kesemuanya adalah objek nyata (Suryati \& Purnama, 2015). 


\section{METODE PENELITIAN}

\section{Tempat Penelitian}

Penelitian ini dilaksanakan di Sekolah Luar Biasa Dharma Wanita, Jln. Kapten Pierre Tendean No.17, Lingkar Timur, Singaran Pati, Kota Bengkulu.

\section{Spesifikasi Hardware dan Software}

Perangkat keras (Hardware) yang digunakan penulis didalam melakukan penelitian ini adalah laptop dengan spesifikasi; 1) laptop Asus A455L, 2) processor Intel(R) Core(TM) i3-5005u, $2.0 \mathrm{GHz}$, 3) RAM 4GB, 4) HDD 500GB, 5) Printer. Spesifikasi perangkat lunak (Sofware) yang digunakan didalam penelitian ini adalah; 1) windows 10 Enterprise 64bit, 2) bahasa Pemograman VB.NET 2010, 3) microsoft Office, 4) microsoft Acces

\section{Metode Pengumpulan Data}

Untuk memperoleh data yang dapat menunjang aplikasi ini, maka diperlukan data teoritis dan data lapangan untuk mendapatkan data dan informasi yang berhubungan dengan sistem pakar yang dibuat. Metode penelitian yang dilakukan adalah sebagai berikut :

Studi pustaka dilakukan dengan cara menelusuri perpustakaan dan tokotoko buku yang ada di kota Bengkulu dan mempelajarinya, serta dengan memanfaatkan pustaka digital yang ada di beberapa situs internet.

Studi laboratorium, yaitu dengan cara melakukan praktek langsung implementasi program yang teah dibuaat pada tempat penelitian, seperti yang telah disebut di atas.

\section{Analisa Data}

Golongan anak reterdasi adalah sebagai berikut, jumlah golongan anak reterdasi mental ada 3 macam golongan yakni sebagai berikut :

Tabel 2. Golongan Anak Reterdasi Mental

\begin{tabular}{lll}
\hline Kode Golongan & \multicolumn{3}{l}{ Golongan } & \\
\hline GOL01 & Anak Reterdasi & Mental \\
& Ringan & \\
GOL02 & Anak Reterdasi & Mental \\
& Sedang & \\
GOL03 & Anak Reterdasi & Mental \\
& Berat & \\
\hline
\end{tabular}

Data-data gejala dalam sistem pakar pengelompokan anak reterdasi mental ini berjumlah 23 gejala. Adapun data-data gejala tersebut dapat dilihat pada tabel dibawah ini:

Tabel. 3 Gejala Anak Reterdasi Mental

\begin{tabular}{|c|c|}
\hline $\begin{array}{l}\text { Kode } \\
\text { gejala }\end{array}$ & Gejala \\
\hline GJL01 & Memiliki IQ antara $50-70$ \\
\hline GJL02 & Berbicara Lancar \\
\hline GJL03 & $\begin{array}{l}\text { Mampu mengikuti pelajaran } \\
\text { akademik }\end{array}$ \\
\hline GJL04 & $\begin{array}{l}\text { Kesulitan belajar (Lamban } \\
\text { Menangkap Pelajaran) }\end{array}$ \\
\hline GJL05 & Mampu menyesuaikan diri \\
\hline GJL06 & Mampu mengurus diri \\
\hline GJL07 & $\begin{array}{l}\text { Mampu bergaul dengan orang } \\
\text { lain }\end{array}$ \\
\hline GJL08 & Perkembangan Fisik normal \\
\hline GJL09 & $\begin{array}{l}\text { Perhatian dan ingatannya sangat } \\
\text { mudah terganggu }\end{array}$ \\
\hline GJL10 & $\begin{array}{l}\text { Kurang dapat mengendalikan diri } \\
\text { (Emosional) }\end{array}$ \\
\hline GJL11 & $\begin{array}{l}\text { Mampu membedakan bahaya dan } \\
\text { bukan bahaya }\end{array}$ \\
\hline GJL12 & Memiliki IQ antara $30-50$ \\
\hline GJL13 & Perkembangan fisik terganggu \\
\hline GJL14 & $\begin{array}{l}\text { Hampir tidak bisa mengikuti } \\
\text { pelajaran akademik }\end{array}$ \\
\hline GJL15 & Belajar secara membeo \\
\hline GJL16 & $\begin{array}{l}\text { Perkembangan bahasanya } \\
\text { terbatas }\end{array}$ \\
\hline GJL17 & Memiliki IQ dibawah 30 \\
\hline GJL18 & Belum mampu mengurus diri \\
\hline GJL19 & $\begin{array}{l}\text { Belum mampu membedakan } \\
\text { bahaya dan bukan bahaya }\end{array}$ \\
\hline GJL20 & Belum mampu menyesuaikan diri \\
\hline GJL21 & $\begin{array}{l}\text { Kemampuan berbicara sangat } \\
\text { terbatas }\end{array}$ \\
\hline GJL22 & $\begin{array}{l}\text { Belum mampu membedakan } \\
\text { yang baik dan buruk }\end{array}$ \\
\hline GJL23 & Keterbatasan dalam berfikir dan \\
\hline
\end{tabular}


berkomunikasi

Dari pengetahuan berupa golongan dan gejala anak reterdasi, maka dapat dibuat baris pengetahuan berupa hubungan atau keterkaitan yang ada antara golongan dan gejala anak reterdasi mental beserta bobot gejala yang diberikan oleh pakar. Hubungan relasi tersebut dapat dilihat pada tabel 4 dibawah ini:

Tabel. 4 Relasi Antara Golongan dan Gejala

\begin{tabular}{lllll}
\hline \multirow{2}{*}{ Kode } & \multicolumn{3}{c}{ Kode golongan } & Bobo \\
\cline { 2 - 4 } gejala & $\begin{array}{c}\text { Gol } \\
\text { 01 }\end{array}$ & $\begin{array}{c}\text { Gol } \\
\mathbf{0 2}\end{array}$ & $\begin{array}{c}\text { Gol } \\
\mathbf{0 3}\end{array}$ & $\mathbf{t}$ \\
\hline GJL01 & $*$ & & & 0.9 \\
GJL02 & $*$ & & & 0.5 \\
GJL03 & $*$ & & & 0.5 \\
GJL04 & $*$ & & & 0.8 \\
GJL05 & & $*$ & & 0.3 \\
GJL06 & & $*$ & & 0.3 \\
GJL07 & $*$ & & & 0.3 \\
GJL08 & $*$ & & & 0.4 \\
GJL09 & $*$ & & & 0.8 \\
GJL10 & $*$ & & & 0.8 \\
GJL11 & & $*$ & & 0.4 \\
GJL12 & & $*$ & & 0.4 \\
GJL13 & & $*$ & $*$ & 0.4 \\
GJL14 & & $*$ & & 0.9 \\
GJL15 & & $*$ & & 0.7 \\
GJL16 & & $*$ & $*$ & 0.7 \\
GJL17 & & & $*$ & 0.8 \\
GJL18 & & & $*$ & 0.8 \\
GJL19 & & & $*$ & 0.8 \\
GJL20 & & & $*$ & 0.8 \\
GJL21 & & & $*$ & 0.8 \\
GJL22 & & & $*$ & 0.5 \\
GJL23 & & & &
\end{tabular}

Dalam kaidah produksi (Rule Base) biasanya dituliskan dalam bentuk jika maka (IF-THEN). Pada perancangan basis pengetahuan sistem pakar ini premis adalah gejala dan konklusi adalah golongan anak reterdasi mental, sehingga bentuk pernyataannya adalah JIKA [Gejala] MAKA [Golongan].

\section{Perancangan Sistem}

Setelah melakukan analisa sistem, maka yang perlu dilakukan selanjutnya adalah perancangan sistem.Perancangan sistem dalam sistem pakar ini adalah terdiri dari bagian yaitu perancangan data flow diagram (DFD), perancangan database dan perancangan interface.

Data Flow Diagram (DFD)

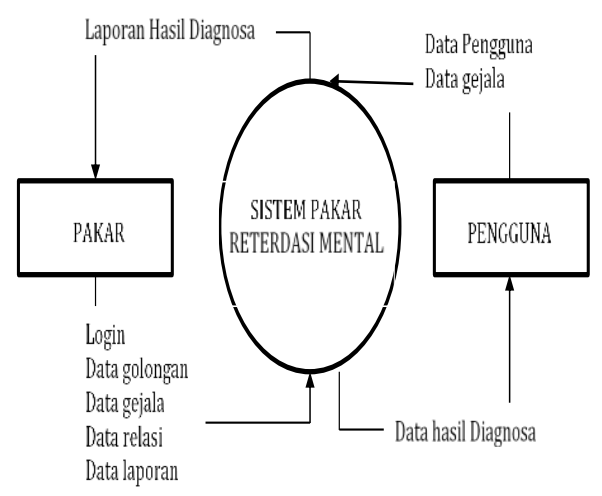

\section{Gambar. 4 Diagram Konteks}

Diagram detail di atas menunjukan aliran data terdapat beberapa proses yang melibatkan entitas seorang pakar dan pengguna.

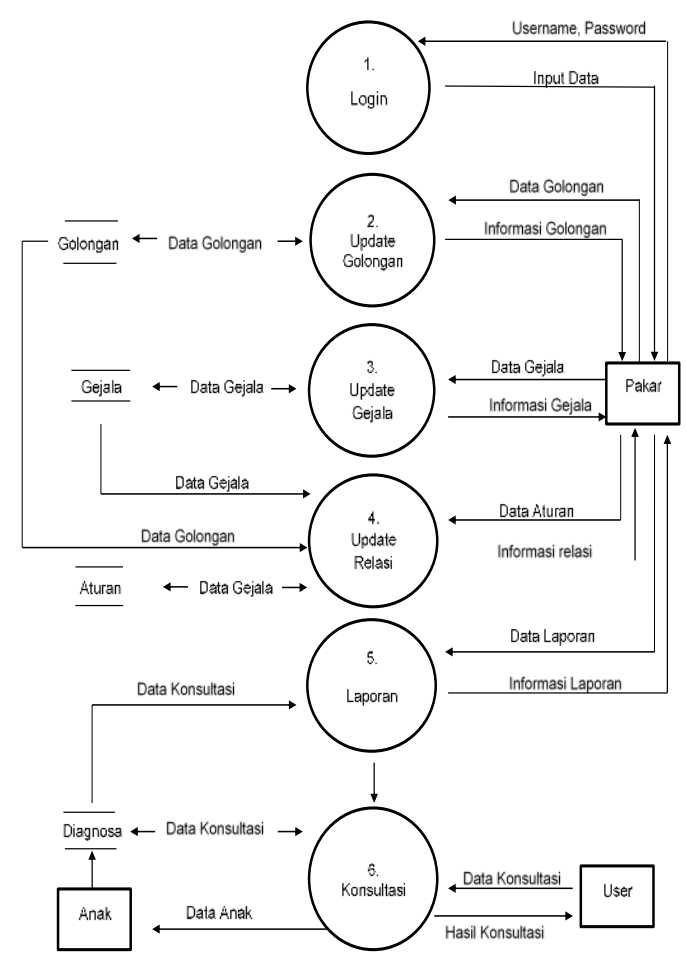

Gambar. 5 Diagram Level 0 


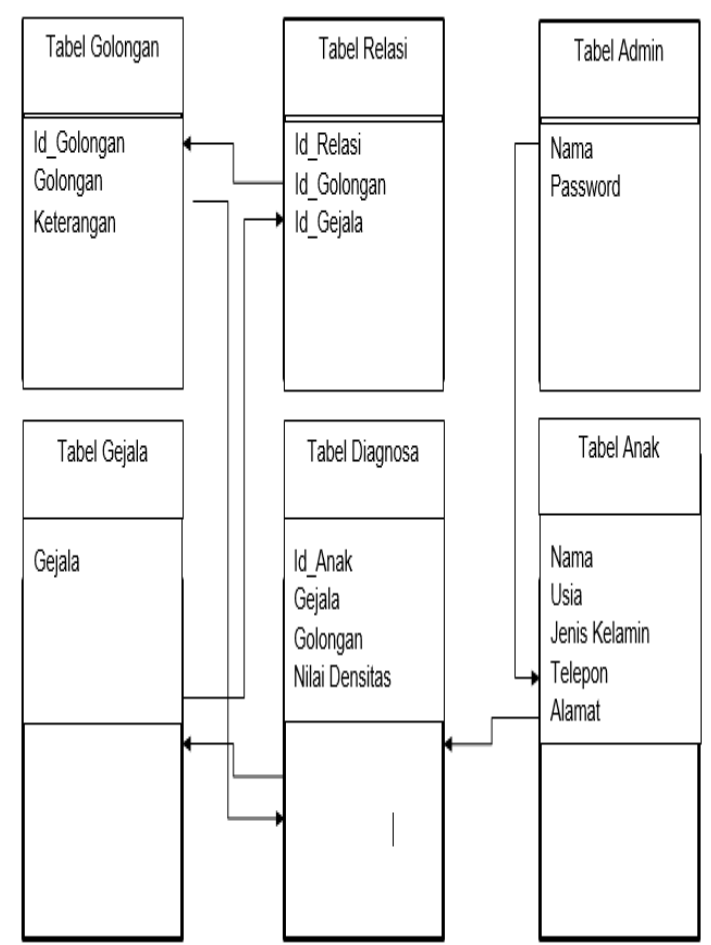

Gambar. 6 Tabel Relasi

\section{Rancangan Struktur Menu Program}

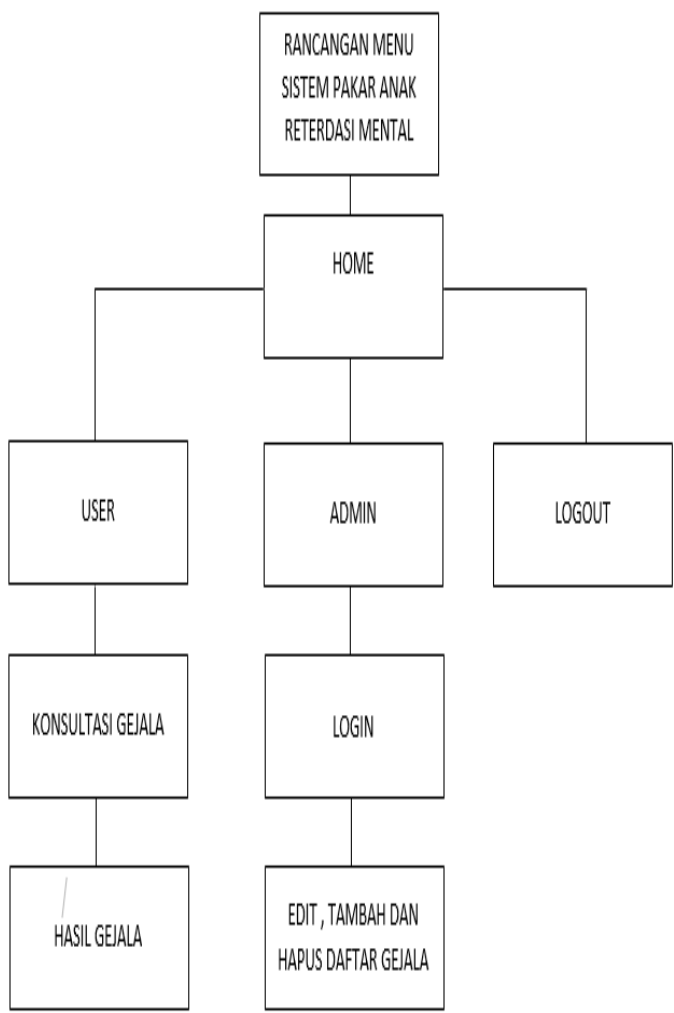

Gambar. 7 Struktur Menu Sistem Pakar Anak Reterdasi

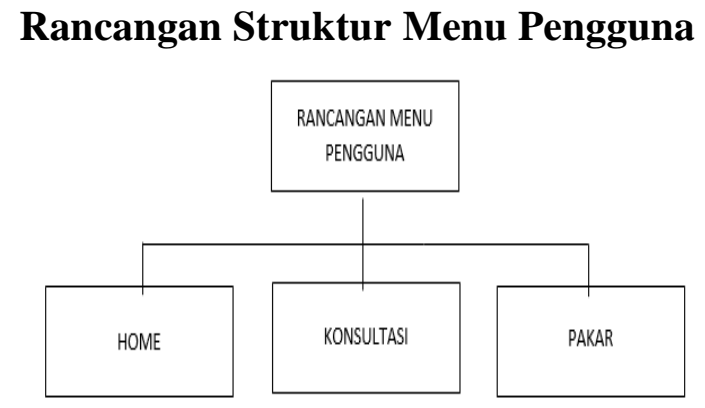

Gambar. 8 Struktur Menu Pengguna

\section{Rancangan Struktur Menu Pakar}

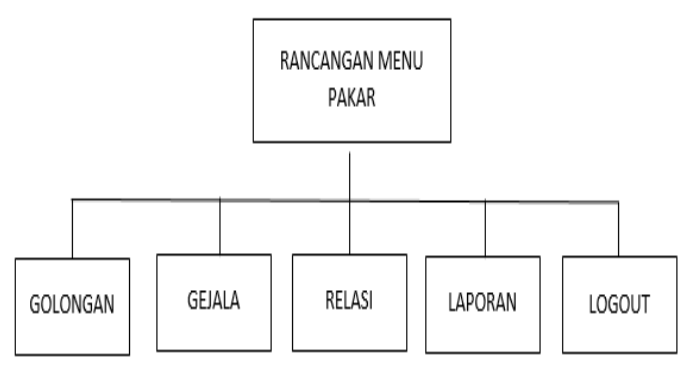

Gambar 9. Struktur Menu Pakar

\section{HASIL DAN PEMBAHASAN}

Tampilan saat pertama kali sistem dijalankan. Terdapat menu profil, konsultasi, dan pakar bila user ingin melakukan konsultasi user wajib mengisi data anak yang akan di diagnosa dengan memilih konsultasi. Menu pakar digunakan oleh pakar untuk login masuk ke halaman pakar.

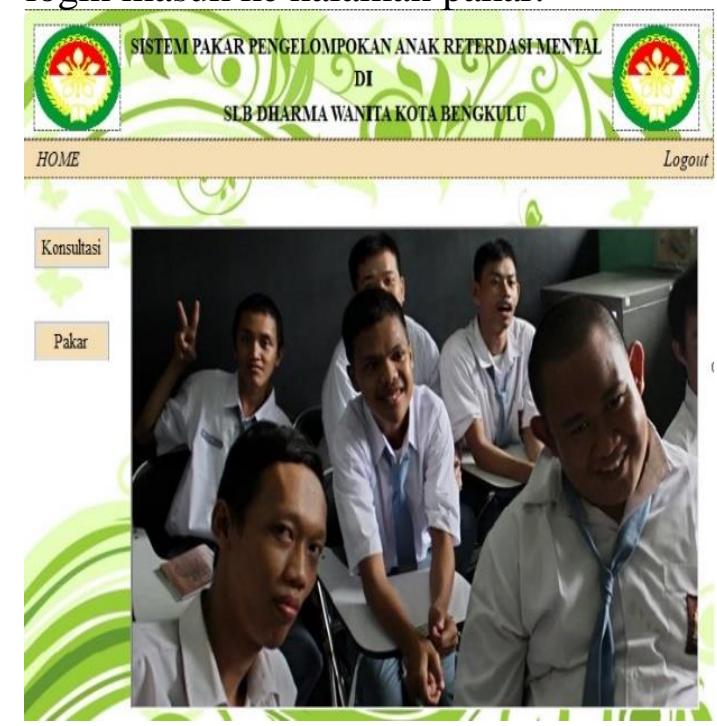

Gambar 10. Beranda 


\section{Halaman Input Data Anak}

Berikut gambar halaman untuk mengisi data anak yang akan di konsultasikan, data yang diisi harus lengkap dan benar. Setelah data diisi dengan benar, selanjutnya user dapat memilih tombol lanjut untuk menuju halaman pemilihan data gejala.

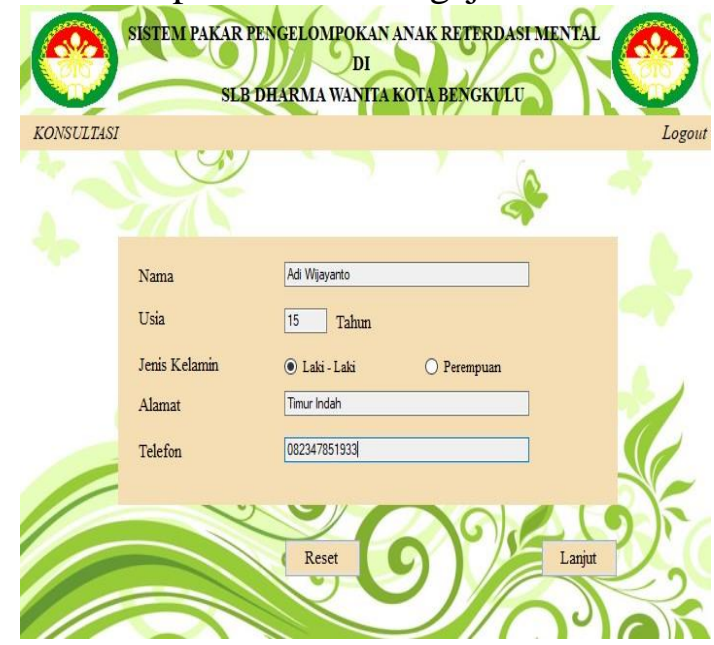

Gambar 11. Input Data Anak

\section{Halaman Pemilihan Gejala}

Agar sistem dapat mengkalkulasikan kemungkinan dari suatu gejala pada sistem pakar dimana sering ditemukan jawaban yang tidak memiliki kepastian penuh. Ketidakpastian ini dapat berupa hasil suatu kejadian. Hasil yang tidak pasti disebabkan oleh beberapa faktor, yaitu aturan yang tidak pasti dan jawaban pengguna yang tidak pasti atas suatu pilihan gejala yang diberikan oleh sistem.

Hal ini sangat mudah dilihat pada sistem diagnosis gangguan, dimana pakar tidak dapat mendefinisikan hubungan antara gejala dengan penyebabnya secara pasti dan pasien tidak dapat merasakan suatu gejala dengan pasti pula. Pada akhirnya akan ditemukan banyak kemungkinan diagnosis. Dengan perhitungan menggunakan algoritma K-Means nilai densitas yang diberikan dapat digunakan sebagai acuan untuk menunjukan besarnya kepercayaan.

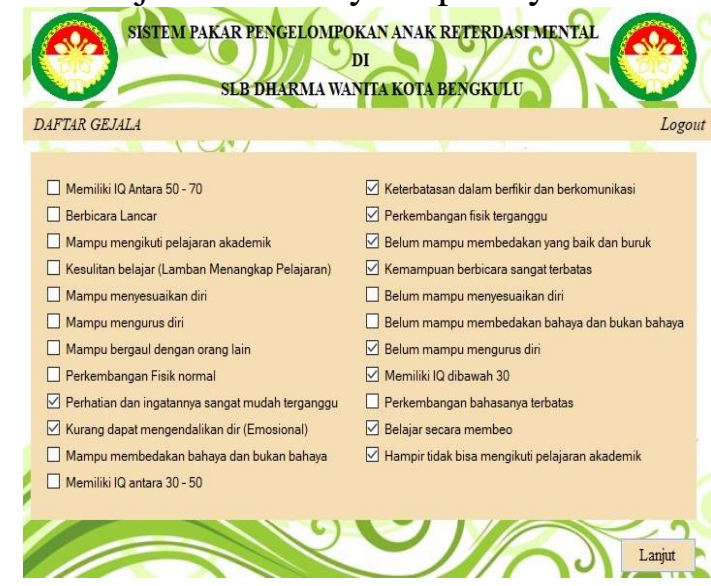

\section{Gambar 12. Daftar Gejala Konsultasi}

Agar sistem data menghitung dan diagnosa kelompok anak reterdasi mental yang dialami oleh anak, user wajib memilih beberapa daftar gejala yang ditampilkan sesuai dengan gejala yang dialami oleh anak, setiap gejalagejala yang di tampilkan memiliki nilai presentasi, untuk dapat menghitung probabilitas. Berikut penerapan rumus dari teori algoritma k_means.

\begin{tabular}{lccccccccccc}
\hline $\begin{array}{l}\text { Sample } \\
\text { Data }\end{array}$ & G1 & G2 & G3 & G4 & G5 & G6 & G7 & G8 & G9 & G10 & $\begin{array}{l}\text { Kelompok / } \\
\text { Cluster }\end{array}$ \\
\hline 1 & 0,9 & 0,8 & 0,4 & 0,8 & 0,4 & 0,7 & 0,7 & 0,8 & 0,8 & 0,0 & \\
\hline 2 & 0,9 & 0,5 & 0,5 & 0,3 & 0,3 & 0,4 & 0,4 & 0,8 & 0,0 & 0,0 & \\
\hline 3 & 0,9 & 0,8 & 0,4 & 0,8 & 0,4 & 0,8 & 0,8 & 0,0 & 0,0 & 0,0 & \\
\hline 4 & 0,8 & 0,4 & 0,8 & 0,4 & 0,4 & 0,8 & 0,8 & 0,5 & 0,0 & 0,0 & \\
\hline 5 & 0,8 & 0,4 & 0,9 & 0,7 & 0,8 & 0,8 & 0,8 & 0,8 & 0,5 & 0,0 & \\
\hline
\end{tabular}


Kita akan mengaplikasikan K-Means Clustering untuk data diatas menjadi 3 cluster. Pertama kita akan hitung Centroid.

Tabel. 6 Cluster

\begin{tabular}{lllllllllll}
\hline Cluster & C1 & C2 & C3 & C4 & C5 & C6 & C7 & C8 & C9 & C10 \\
\hline K1 & 0,9 & 0,8 & 0,4 & 0,8 & 0,4 & 0,7 & 0,7 & 0,8 & 0,8 & 0,0 \\
\hline K2 & 0,9 & 0,5 & 0,5 & 0,3 & 0,3 & 0,4 & 0,4 & 0,8 & 0,0 & 0,0 \\
\hline K3 & 0,9 & 0,8 & 0,4 & 0,8 & 0,4 & 0,8 & 0,8 & 0,0 & 0,0 & 0,0 \\
\hline
\end{tabular}

Perhitungan menggunakan persamaan Euclidean Distance

$$
[(x, y),(a, b)]=\sqrt{(x-a)^{2}+(y-b)^{2}}
$$

Perhitungan Pertama ;

Jarak dari Cluster 1 ke cluster $2(0.9,0.8,0.4,0.8,0.4,0.7,0.7,0.8,0.8,0.0) \leftrightarrow$ $(0.9,0.5,0.5,0.3,0.3,0.4,0.4,0.8,0.0,0.0)=$

$$
\sqrt{\begin{array}{c}
(0.9-0.9)^{2}+(0.8-0.5)^{2}+(0.4-0.5)^{2}+(0.8-0.3)^{2}+(0.4-0.3)^{2}+(0.7-0.4)^{2} \\
+(0.7-0.4)^{2}+(0.8-0.8)^{2}+(0.8-0.0)^{2}+(0.0-0.0)^{2}=1,18
\end{array}}
$$

Jarak dari cluster 1 ke cluster $3(0.9,0.8,0.4,0.8,0.4,0.7,0.7,0.8,0.8,0.0)$

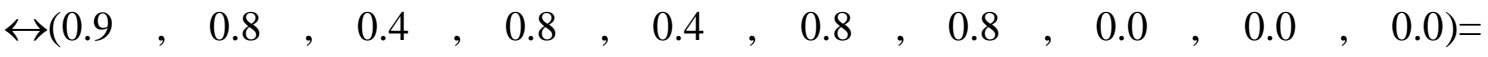
$\sqrt{\begin{array}{c}(0.9-0.9)^{2}+(0.8-0.8)^{2}+(0.4-0.4)^{2}+(0.8-0.8)^{2}+(0.4-0.4)^{2}+(0.7-0.8)^{2} \\ +(0.7-0.8)^{2}+(0.8-0.0)^{2}+(0.8-0.0)^{2}+(0.0-0.0)^{2}=1,30\end{array}}$

Jarak dari cluster 2 ke cluster $1(0.9,0.5,0.5,0.3,0.3,0.4,0.4,0.8,0.0,0.0) \leftrightarrow$ $(0.9,0.8,0.4,0.8,0.4,0.7,0.7,0.8,0.8,0.0)=$

$$
\sqrt{\begin{array}{c}
(0.9-0.9)^{2}+(0.8-0.5)^{2}+(0.4-0.5)^{2}+(0.8-0.3)^{2}+(0.4-0.3)^{2}+(0.7-0.4)^{2} \\
+(0.7-0.4)^{2}+(0.8-0.8)^{2}+(0.8-0.0)^{2}+(0.0-0.0)^{2}=1,18
\end{array}}
$$

Jarak dari cluster 2 ke cluster $3(0.9,0.5,0.5,0.3,0.3,0.4,0.4,0.8,0.0,0.0) \leftrightarrow$ $(0.9,0.8,0.4,0.8,0.4,0.8,0.8,0.0,0.0,0.0)=$

$$
\sqrt{\begin{array}{c}
(0.9-0.9)^{2}+(0.5-0.8)^{2}+(0.5-0.4)^{2}+(0.3-0.8)^{2}+(0.3-0.4)^{2}+(0.4-0.8)^{2} \\
+(0.4-0.8)^{2}+(0.8-0.0)^{2}+(0.0-0.0)^{2}+(0.0-0.0)^{2}=1,32
\end{array}}
$$

Jarak dari cluster 3 ke cluster $1(0.9,0.8,0.4,0.8,0.4,0.8,0.8,0.0,0.0$, $0.0) \leftrightarrow(0.9,0.8,0.4,0.8,0.4,0.7,0.7,0.8,0.8,0.0)=$

$$
\sqrt{\begin{array}{c}
(0.9-0.9)^{2}+(0.8-0.8)^{2}+(0.4-0.4)^{2}+(0.8-0.8)^{2}+(0.4-0.4)^{2}+(0.8-0.7)^{2} \\
+(0.8-0.7)^{2}+(0.0-0.8)^{2}+(0.0-0.8)^{2}+(0.0-0.0)^{2}=1,30
\end{array}}
$$

Jarak dari cluster 3 ke cluster $2(0.9,0.8,0.4,0.8,0.4,0.8,0.8,0.0,0.0$, $0.0) \leftrightarrow(0.9,0.5,0.5,0.3,0.3,0.4,0.4,0.8,0.0,0.0)=$

$$
\sqrt{\begin{array}{c}
(0.9-0.9)^{2}+(0.8-0.5)^{2}+(0.4-0.5)^{2}+(0.8-0.3)^{2}+(0.4-0.3)^{2}+(0.8-0.4)^{2} \\
+(0.8-0.4)^{2}+(0.0-0.8)^{2}+(0.0-0.0)^{2}+(0.0-0.0)^{2}=1,32
\end{array}}
$$


Sehingga :

Tabel. 7 Hasil Perhitungan

\begin{tabular}{lllll}
\hline \multirow{2}{*}{ Dataset } & \multicolumn{3}{c}{ Euclidean Distance } & Kelompok \\
\cline { 2 - 5 } & Cluster 1 & Cluster 2 & Cluster 3 & Cluster \\
\hline Adi Wijayanto & 0,0 & 1,18 & 1,30 & 1 \\
\hline Redo Putra & 1,18 & 0,0 & 1,32 & 2 \\
\hline Ayu Putri & 1,30 & 1,32 & 0,0 & 3 \\
\hline
\end{tabular}

Perhitungan kedua.

Langkah selanjutnya kita beralih ke data 4 yaitu $(0.8,0.4,0.8,0.4,0.4,0.8,0.8,0.5$ , $0.0,0.0)$. Kita mulai menghitung jarak dataset terhadap cluster $1(0.9,0.8,0.4$

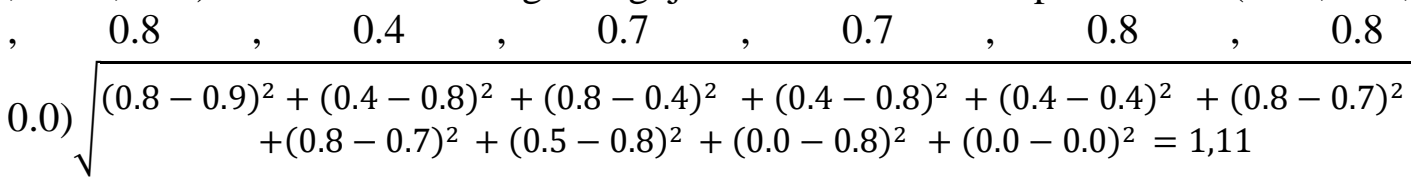

Kemudian kita hitung jarak dataset terhadap cluster 2.

$$
\sqrt{\begin{array}{c}
(0.8-0.9)^{2}+(0.4-0.5)^{2}+(0.8-0.5)^{2}+(0.4-0.3)^{2}+(0.4-0.3)^{2}+(0.8-0.4)^{2} \\
+(0.8-0.4)^{2}+(0.5-0.8)^{2}+(0.0-0.0)^{2}+(0.0-0.0)^{2}=0,73
\end{array}}
$$

Kemudian hitung jarak dataset terhadap cluster 3.

$$
\sqrt{\begin{array}{c}
(0.8-0.9)^{2}+(0.4-0.8)^{2}+(0.8-0.4)^{2}+(0.4-0.8)^{2}+(0.4-0.4)^{2}+(0.8-0.8)^{2} \\
+(0.8-0.8)^{2}+(0.5-0.0)^{2}+(0.0-0.0)^{2}+(0.0-0.0)^{2}=0,86
\end{array}}
$$

Sehingga didapatkan :

Tabel. 8 Hasil Penrhitungan

\begin{tabular}{lllll}
\hline Dataset & \multicolumn{2}{l}{ Euclidean Distance } & \multirow{2}{*}{ Kelompok Cluster } \\
\cline { 2 - 4 } & Cluster 1 & Cluster 2 & Cluster 3 & \\
\hline $\begin{array}{l}\text { Dataset K-4 } \\
\text { Cika Cantika }\end{array}$ & 1,11 & 0,73 & 0,86 & 2 \\
\hline
\end{tabular}

Dataset ke-4 masuk dalam kelompok cluster 2 , karena jarak minimum / terdekat dataset adalah terhadap cluster 2 yaitu 0,73 dan masuk kedalam golongan anak reterdasi mental sedang.Kemudian kita update Centroid :

\begin{tabular}{|c|c|c|c|c|c|c|c|c|c|c|}
\hline Custer & C1 & $C 2$ & $\mathrm{C} 3$ & $\mathrm{CA}$ & $\mathrm{CS}$ & C6 & C7 & $\mathrm{CB}$ & C9 & C10 \\
\hline $\mathrm{K} 1$ & 0,9 & 0,8 & 0,4 & 0,8 & 0,4 & 0,7 & 0,7 & 0,8 & 0,8 & 0,0 \\
\hline $\bar{K} 2$ & $\begin{array}{l}=\frac{0.5+0.8}{2} \\
=0.85\end{array}$ & $\begin{array}{l}=\frac{0.5+0.4}{2} \\
=0.45\end{array}$ & $\begin{array}{l}=\frac{0.5+0.8}{2} \\
=0.65\end{array}$ & $\begin{array}{l}=\frac{0.3+0.7}{2} \\
=0.35\end{array}$ & $\begin{array}{l}=\frac{0.5+0.7}{2} \\
=0.35\end{array}$ & $\begin{array}{l}=\frac{0.7+0.8}{2} \\
=0.6\end{array}$ & $\begin{array}{l}=\frac{0.7+0.8}{2} \\
=0.6\end{array}$ & $\begin{array}{l}=\frac{0.8+0.5}{2} \\
=0.65\end{array}$ & $\begin{array}{l}=\frac{0.0+0.0}{2} \\
=0.0\end{array}$ & $\begin{array}{l}=\frac{0.0+0.0}{2} \\
=0.0\end{array}$ \\
\hline $\mathrm{K} 3$ & 0,9 & 0,8 & 0,4 & 0,8 & 0,4 & 0,8 & 0,8 & 0,0 & 0,0 & 0,0 \\
\hline
\end{tabular}

Tabel. 9 Hasil Perhitungan

Jadi Cluster Centroid yang baru adalah sebagai berikut : 
Tabel. 10 Hasil Perhitungan

\begin{tabular}{lllllllllll}
\hline Cluster & C1 & C2 & C3 & C4 & C5 & C6 & C7 & C8 & C9 & C10 \\
\hline K1 & 0,9 & 0,8 & 0,4 & 0,8 & 0,4 & 0,7 & 0,7 & 0,8 & 0,8 & 0,0 \\
\hline K2 & 0.85 & 0.45 & 0.65 & 0.35 & 0.35 & 0.6 & 0.6 & 0.65 & 0,0 & 0,0 \\
\hline K3 & 0,9 & 0,8 & 0,4 & 0,8 & 0,4 & 0,8 & 0,8 & 0,0 & 0,0 & 0,0 \\
\hline
\end{tabular}

Perhitungan ketiga

Langkah selanjutnya kita beralih ke data 5 yaitu $(0.8,0.4,0.9,0.7,0.8,0.8,0.8,0.8$ , $0.5,0.0)$. Kita mulai menghitung jarak dataset terhadap cluster $1(0.9,0.8,0.4,0.8$, $0.4,0.7,0.7,0.8,0.8,0.0)$

$$
\sqrt{\begin{array}{c}
(0.8-0.9)^{2}+(0.4-0.8)^{2}+(0.9-0.4)^{2}+(0.7-0.8)^{2}+(0.8-0.4)^{2}+(0.8-0.7)^{2} \\
+(0.8-0.7)^{2}+(0.8-0.8)^{2}+(05-0.8)^{2}+(0.0-0.0)^{2}=0,41
\end{array}}
$$

Kemudian kita hitung jarak dataset terhadap cluster 2 .

$\sqrt{\begin{array}{c}(0.8-0.85)^{2}+(0.4-0.45)^{2}+(0.9-0.65)^{2}+(0.7-0.35)^{2}+(0.8-0.35)^{2}+(0.8-0.6)^{2} \\ +(0.8-0.6)^{2}+(0.8-0.65)^{2}+(0.5-0.0)^{2}+(0.0-0.0)^{2}=0,86\end{array}}$

Kemudian hitung jarak dataset terhadap cluster 3 .

$$
\sqrt{\begin{array}{c}
(0.8-0.9)^{2}+(0.4-0.8)^{2}+(0.9-0.4)^{2}+(0.7-0.8)^{2}+(0.8-0.4)^{2}+(0.8-0.8)^{2} \\
+(0.8-0.8)^{2}+(0.8-0.0)^{2}+(0.5-0.0)^{2}+(0.0-0.0)^{2}=1,21
\end{array}}
$$

Sehingga didapatkan :

Tabel. 11 Hasil Perhitungan

\begin{tabular}{lllll}
\hline Dataset & \multicolumn{2}{l}{ Euclidean Distance } & \multirow{2}{*}{ Kelompok Cluster } \\
\cline { 2 - 4 } & Cluster 1 & Cluster 2 & Cluster 3 & \\
\hline $\begin{array}{l}\text { Dataset K-5 } \\
\text { Cika Cantika }\end{array}$ & 0,41 & 0,86 & 1,21 & \multirow{2}{*}{1} \\
\hline
\end{tabular}

Dataset ke-5 masuk dalam kelompok cluster 1, karena jarak minimum / terdekat dataset adalah terhadap cluster 1 yaitu 0,41 dan masuk kedalam golongan anak reterdasi mental ringan.Kemudian kita update Centroid:

\begin{tabular}{|c|c|c|c|c|c|c|c|c|c|c|}
\hline $\begin{array}{l}\text { Cluste } \\
\text { r }\end{array}$ & C1 & C2 & $\mathrm{C3}$ & C4 & C5 & C6 & C7 & C8 & C9 & C10 \\
\hline \multirow[t]{2}{*}{ K1 } & $0.9+0.8$ & $0.8+0.4$ & $0.4+0 . \mathrm{C}$ & $0.8+0.7$ & $0.4+1$ & $0.7+1$ & $0.7+1$ & $0.8+0 . \mathcal{E}$ & $0.8+0.5$ & $0.0+0 . c$ \\
\hline & $\begin{array}{l}=\frac{2}{2} \\
=0.85\end{array}$ & $\begin{array}{l}=-\frac{2}{2} \\
=0.6\end{array}$ & $\begin{array}{l}=\frac{2}{2} \\
=0.65\end{array}$ & $\begin{array}{l}=\frac{2}{2} \\
=0.75\end{array}$ & $\begin{array}{l}=\overline{2} \\
=0.6\end{array}$ & $\begin{array}{l}=\frac{2}{2} \\
=0.75\end{array}$ & $\begin{array}{l}=\frac{2}{2} \\
=0.75\end{array}$ & $\begin{array}{l}=\frac{2}{2} \\
=0.8\end{array}$ & $\begin{array}{l}=\frac{2}{2} \\
=0,65\end{array}$ & $\begin{array}{l}=\frac{2}{2} \\
=0,0\end{array}$ \\
\hline K2 & 0.85 & 0.45 & 0.65 & 0.35 & 0.35 & 0.6 & 0.6 & 0.65 & 0,0 & 0,0 \\
\hline $\mathrm{K} 3$ & 0,9 & 0,8 & 0,4 & 0,8 & 0,4 & 0,8 & 0,8 & 0,0 & 0,0 & 0,0 \\
\hline
\end{tabular}

Tabel. 12 Hasil Perhitungan

Jadi Cluster Centroid yang baru adalah sebagai berikut :

Tabel 13 Hasil Perhitungan

\begin{tabular}{lllllllllll}
\hline Cluster & C1 & C2 & C3 & C4 & C5 & C6 & C7 & C8 & C9 & C10 \\
\hline $\mathrm{K} 1$ & 0.85 & 0.6 & 0.65 & 0,75 & 0.6 & 0,75 & 0,75 & 0,8 & 0.65 & 0,0 \\
\hline $\mathrm{K} 2$ & 0.85 & 0.45 & 0.65 & 0.35 & 0.35 & 0.6 & 0.6 & 0.65 & 0,0 & 0,0 \\
\hline $\mathrm{K} 3$ & 0,9 & 0,8 & 0,4 & 0,8 & 0,4 & 0,8 & 0,8 & 0,0 & 0,0 & 0,0 \\
\hline
\end{tabular}


Semua data telah kita dapatkan, dan masing-masing data sudah terkelompokkan berdasarkan cluster 1 , cluster 2 dan cluster 3. Selanjutnya kita input hasil pengelompokkanya pada table pertama. Jadi hasilnya seperti berikut :

Tabel. 14 Hasil Perhitungan

\begin{tabular}{lllll}
\hline Sample Data & Centroid1 & Centroid2 & Centroid3 & Kelompok / Cluster \\
\hline Adi Wijayanto & 0,0 & 1,18 & 1,30 & $\begin{array}{l}\text { Anak Reterdasi Mental } \\
\text { Ringan }\end{array}$ \\
\hline Redo Putra & 1,18 & 0,0 & 1,32 & $\begin{array}{l}\text { Anak Reterdasi Mental } \\
\text { Sedang }\end{array}$ \\
\hline Ayu Putri & 1,30 & 1,32 & 0,0 & $\begin{array}{l}\text { Anak Reterdasi Mental } \\
\text { Berat }\end{array}$ \\
\hline Cika Cantika & 1,11 & 0,73 & 0,86 & $\begin{array}{l}\text { Anak Reterdasi Mental } \\
\text { Sedang }\end{array}$ \\
\hline Victor Mandala Putra & 0,41 & 0,86 & 1,21 & $\begin{array}{l}\text { Anak Reterdasi Mental } \\
\text { Ringan }\end{array}$ \\
\hline
\end{tabular}

\section{Hasil Diagnosa}

Berikut adalah halaman hasil diagnosa seorang anak pada hasil ditampilkan nilai densitas golongan anak reterdasi mental yang dialami, beserta kelompok golongan yang sesuai gejala.

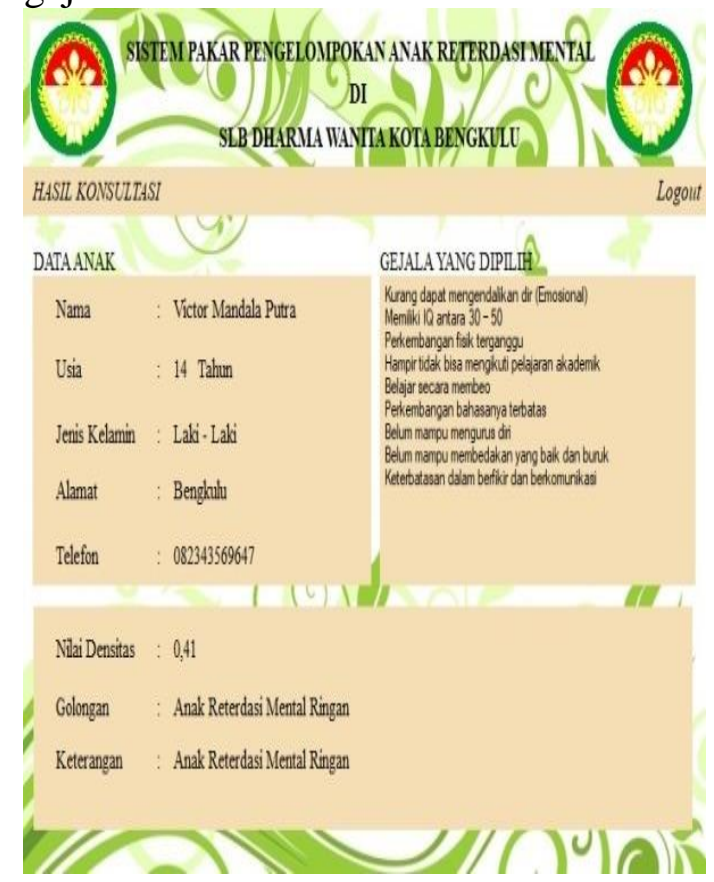

Gambar. 13 Hasil Konsultasi

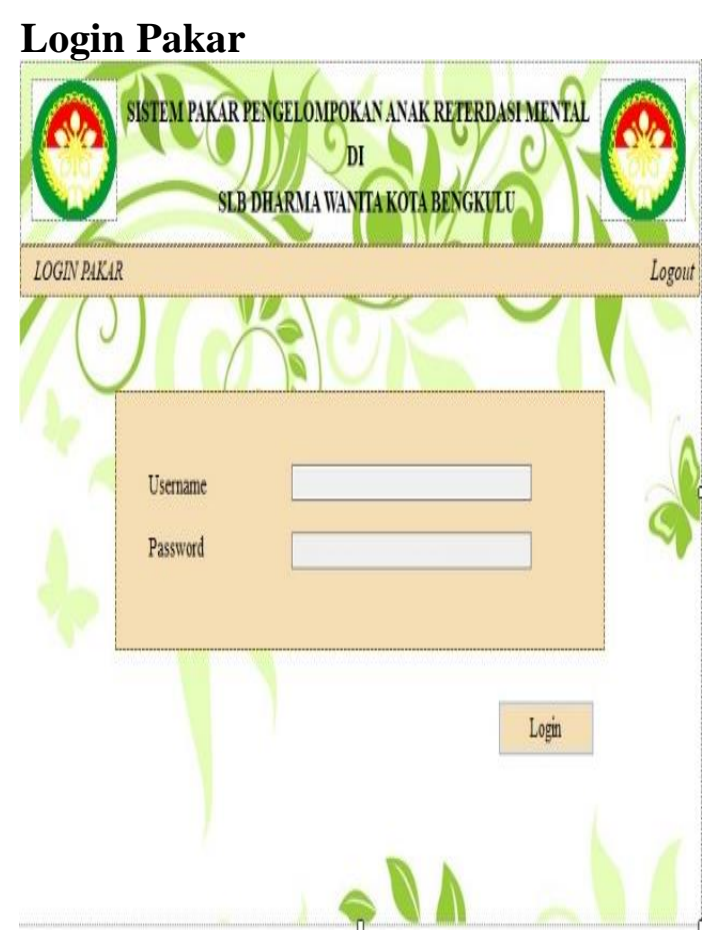

\section{Halaman Pakar}

Berikut tampilan menu pakar. Terdapat menu golongan, gejala, relasi, dan laporan untuk dapat menambah,merubah atau menghapus data golongan, gejala dan relasi seorang pakar dapat memilih menu-menu tersebut. 


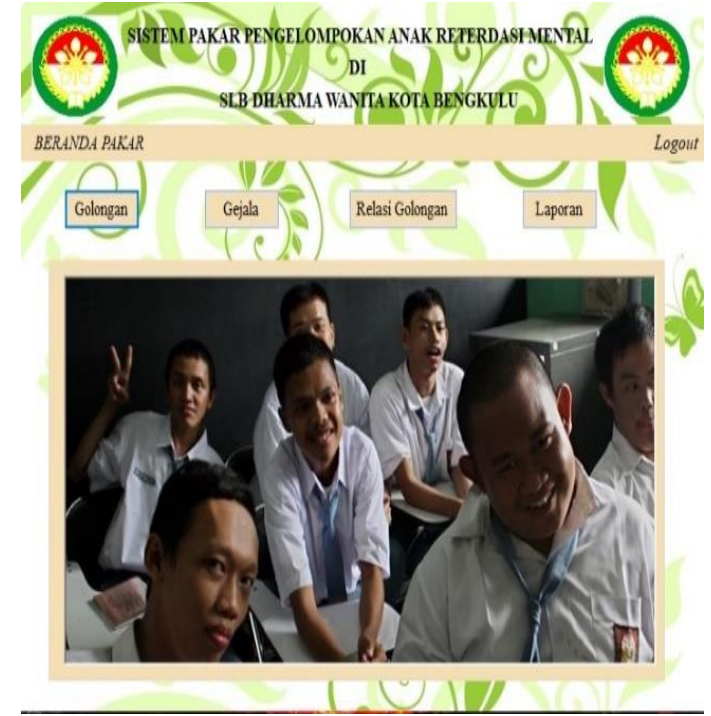

Gambar. 15 Beranda Pakar

\section{Halaman Data Golongan}

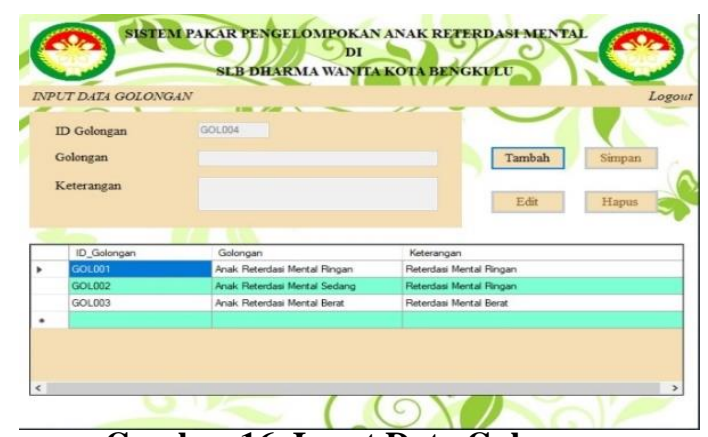

Gambar 16. Input Data Golongan
Halaman Data Gejala

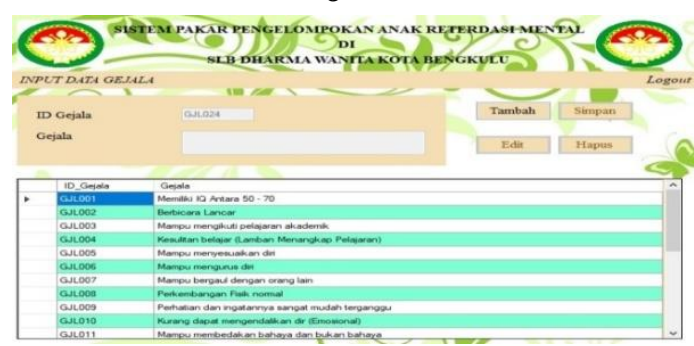

Gambar. 17 Input Data Gejala

\section{Halaman Relas}

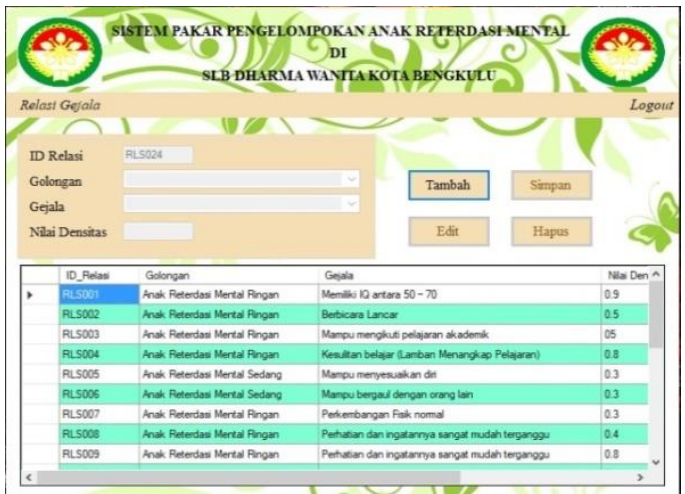

Gambar. 18 Input Data Relasi

Tabel 15. Data Pengelompokan Anak

\begin{tabular}{|c|c|c|c|}
\hline Nama Anak & Gejala & Golongan & Nilai \\
\hline Adi Wijayanto & $\begin{array}{l}\text { - } \text { Memiliki IQ antara } 30-50 \\
\text { - } \quad \text { Kesulitan belajar (Lamban Menangkap } \\
\text { - } \quad \text { Pelajaran) } \\
\text { - } \quad \text { Perhatian dan ingatannya mudah terganggu } \\
\text { - } \quad \text { Belum mampu membedakan yang bahaya dan } \\
\text { - } \text { Bukan bahaya } \\
\text { - Belum Mampu Mengurus diri } \\
\text { - } \quad \text { Perkembangan Bahasa terbatas } \\
\text { - Belajar secara membeo }\end{array}$ & $\begin{array}{l}\text { Anak Reterdasi Mental } \\
\text { Ringan }\end{array}$ & 0,0 \\
\hline Redo Putra & $\begin{array}{ll}\text { - } & \text { Memiliki IQ antara } 50-70 \\
\text { - } & \text { Berbicara Lancar } \\
\text { - } & \text { Mampu mengikuti pelajaran akademik } \\
\text { - } & \text { Mampu menyesuaikan diri } \\
\text { - } & \text { Mampu bergaul dengan orang lain } \\
\text { - } & \text { Perkembangan Fisik normal } \\
\text { - } & \text { Mampu membedakan yang bahaya dan bukan } \\
& \text { bahaya } \\
\text { - } & \text { Belum Mampu Mengurus diri }\end{array}$ & $\begin{array}{l}\text { Anak Reterdasi Mental } \\
\text { Sedang }\end{array}$ & 0,0 \\
\hline Ayu Putri & $\begin{array}{ll} & \text { Memiliki IQ antara } 50-70 \\
\text { - } & \text { Kesulitan belajar (Lamban Menangkap } \\
& \text { Pelajaran) } \\
\text { - } & \text { Perkembangan fisik normal }\end{array}$ & $\begin{array}{l}\text { Anak Reterdasi Mental } \\
\text { Berat }\end{array}$ & 0,0 \\
\hline
\end{tabular}




\begin{tabular}{|c|c|c|c|}
\hline & $\begin{array}{ll}\text { - } & \text { Perhatian dan ingatannya mudah terganggu } \\
\text { - } & \text { Mampu membedakan bahaya dan bukan bahaya } \\
\text { - } & \text { Kemampuan berbicara sangat terbatas } \\
\text { - } & \text { Belum mampu mengurus diri }\end{array}$ & & \\
\hline Cika Cantika & $\begin{array}{ll}\text { - } & \text { Memiliki IQ antara } 30-50 \\
\text { - } & \text { Kesulitan belajar (Lamban Menangkap } \\
\text { - } & \text { Pelajaran) } \\
\text { - } & \text { Mampembangan fisik normal } \\
\text { - } & \text { Perhatian dan ingatannya mudah terganggu } \\
\text { - } & \text { Kemampuan berbicara sangat terbatas } \\
\text { - } & \text { Keterbatasan dalam berpikir dan berkomunikasi } \\
\text { - } & \text { Belum mampu mengurus diri } \\
\end{array}$ & $\begin{array}{l}\text { Anak Reterdasi Mental } \\
\text { Sedang }\end{array}$ & 0,73 \\
\hline $\begin{array}{l}\text { Victor Mandala } \\
\text { Putra }\end{array}$ & $\begin{array}{ll}\text { - } & \text { Memiliki IQ di bawah } 30 \\
\text { - } & \text { Kurang dapat mengendalikan diri (Emosional) } \\
\text { - } & \text { Keterbatasan dalam berpikir dan berkomunikasi } \\
\text { - } & \text { Perkembangan fisik terganggu } \\
\text { - } & \text { belum mampu membedakan yang baik dan } \\
\text { - } & \text { Bemampuan berbicara sangat terbatas } \\
\text { - } & \text { Belajar secara membeo } \\
\text { - } & \text { Hampir tidak bisa mengikuti pelajaran }\end{array}$ & $\begin{array}{l}\text { Anak Reterdasi Mental } \\
\text { Ringan }\end{array}$ & 0,41 \\
\hline
\end{tabular}

\section{SIMPULAN}

Dari hasil penelitian ini dapat ditarik kesimpulan mengenai aspek yang menjadi bahasan pada pembangunan aplikasi sistem pakar pengelompokan anak reterdasi mental menggunakan algoritma K-Means , yaitu :

1. Aplikasi ini dapat mendiagnosa tingkat reterdasi anak mental berdasarkan gejala-gejala yang diberikan oleh user.

2. Aplikasi ini mendiagnosa tingkat reterdasi mental berdasarkan nilainilai kemungkinan menggunakan perhitungan algoritma K-Means.

\section{DAFTAR PUSTAKA}

Bastian, A. (2018). Penerapan Algoritma K-Means Clustering Analysis pada Penyakit Menular Manusia (Studi Kasus Kabupaten Majalengka). Jurnal Sistem Informasi, 14(1), 28-34. Retrieved from

http://jsi.cs.ui.ac.id/index.php/jsi/a rticle/view/566

Daeli, F. (2013). Sistem Pakar dalam Menentukan Tingkat IQ Anak yang Mengalami Reterdasi Mental dengan Metode Certainty Factor (Studi Kasus: Pendidikan SLB/B Karya Murni). Pelita Informatka Budi Darma, 4(3), 43-47

Mukhtar, N., \& Samsudin, S. (2014). Sistem Pakar Diagnosa Dampak Penggunaan Softlens Menggunakan Metode Backward Chaining. Jurnal Buana Informatika, 6(1), 21-30

Octavina, Y., \& Fadlil, A. (2014). Sistem Pakar untuk Mendiagnosa Penyakit pada Saluran Pernafasan dan Paru Menggunakan Metode Certainty Factor. Jurnal Sarjana Teknik Informatika, 2(2)

Rismawan, T., \& Kusumadewi, S. (2008). Aplikasi K-Means untuk Pengelompokkan Mahasiswa berdasarkan Nilai Body Mass Index (BMI) \& Ukuran Kerangka. Seminar Nasional Aplikasi Teknologi Informasi (SNATI) 2008, 1907-5022, 43-48

Sularyo, T. S., \& Kadim, M. (2000). Retardasi Mental. Sari Pediartri, 2(3), 170-177

Supartini, W. \& Hindarto, H. (2016). Sistem Pakar Berbasis Web dengan Metode Forward Chaining 
dalam Mendiagnosis Dini

Penyakit Tuberkulosis di Jawa

Timur. Kinetik, 1(3), 147-154

Suryati, S., \& Purnama, B. E. (2010).

Pembangunan Sistem Informasi

Pendataan Rakyat Miskin untuk

Program Beras Miskin(RASKIN)

pada Desa Mantren. Journal

Speed - Sentra Penelitian

Engineering dan Edukasi, 2(4), 32-41

Widiastuti, W., Destiani, D., \& Damiri, D. J. (2012). Aplikasi Sistem Pakar Deteksi Dini pada Penyakit Tuberkulosis. Jurnal Algoritma, 9, 1-10

Wijaya, E. (2013). Analisis Penggunaan Algoritma Breadth First Search dalam Konsep Artificial Intellegencia. Jurnal TIME, 2(2), $18-26$ 